

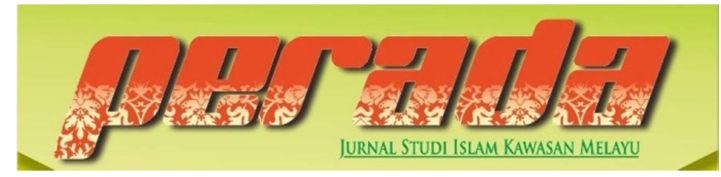

Perada: Jurnal Studi Islam Kawasan Melayu

ISSN 2656-7202 (P) ISSN 2655-6626 (0)

Volume 3 Nomor 1, Januari-Juni 2020

DOI: https://doi.org/10.35961/perada.v3i1.105

\title{
KAJIAN TERHADAP TAFSIR: METODE, PENDEKATAN DAN CORAK DALAM MITRA PENAFSIRAN AL-QUR'AN
}

\author{
Ummi Kalsum Hasibuan \\ UIN Sunan Kalijaga Yogyakarta \\ Ummi220896@gmail.com
}

\begin{abstract}
ABSTRAK
Tulisan ini mengkaji tentang metode, pendekatan dan corak tafsir Alquran. Adapun metode yang digunakan dalam tulisan ini adalah metode deskriptif-analisis. Tulisan ini bertujuan untuk mengupas dan menganalisa tentang metode, pendekatan dan corak dalam tafsir Alquran. Tulisan ini menyimpulkan bahwa; pertama, metode tafsir adalah suatu cara, langkah-langkah, ataupun kerangka yang harus ditempuh ketika melakukan penafsiran Alquran, sehingga dalam hal ini terdapat beberapa metode penafsiran Alquran, yaitu; metode tafsir tahlili, ijmali, muqaran, maudhu'iy dan hermeneutika. Kedua; pendekatan tafsir adalah sudut pandang dari prosesnya tafsir akan membuahkan corak, sehingga antara pendekatan dan corak tafsir itu saling keterkaitan antara keduanya. Adapun pendekatan dalam tafsir adalah pendekatan tekstual, kontekstual, bahasa, historis dan sosio-historis. Ketiga; corak tafsir adalah suatu nuansa, dominasi, warna ataupun kecenderungan pemikiran atau ide yang mendominasi suatu karya tafsir dan yang termasuk kepada corak tafsir Alquran adalah corak falsafi, fiqhi, sufi, 'ilmi, adabi al-ijtima'iy.
\end{abstract}

\section{ABSTRACT}

This paper examines the methods, approaches and styles of interpretation of the Koran. The method used in this paper is descriptive-analysis method. This paper aims to analyze and analyze the methods, approaches and patterns in the interpretation of the Koran. This paper concludes that; first, the method of interpretation is a method, steps, or framework that must be taken when interpreting the Koran, so that in this case there are several methods of interpreting the Koran, namely; the methods of interpretation of tahlili, ijmali, muqaran, maudhu'iy and hermeneutics. Second; the interpretive approach is the point of view of the interpretation process which will produce a style, so that the approach and style of interpretation are interrelated between the two. The approaches to interpretation are textual, contextual, linguistic, historical and socio-historical approaches. Third; Tafsir style is a nuance, domination, color or tendency of thoughts or ideas that dominate a work of interpretation and which is included in the interpretation of the Koran are philosophical, fiqhi, sufi, 'ilmi, adabi al-ijtima'iy features.

Keywords: Alquran, interpretation, methods, approaches, patterns. 


\section{PENDAHULUAN}

Alquran merupakan Kalam Allah SW'T yang Mu'jiz, dipahami oleh Jibril kemudian disampaikan kepada Nabi Muhammad SAW dalam bahasa Arab, ditulis dalam mushaf, mendapat pahala apabila membacanya, diriwayatkan secara mutawwatir, diawali dengan surah al-Fatihah dan diakhiri dengan surah an-Nas. Alquran diturunkan sebagai pedoman, pegangan dan petunjuk bagi manusia untuk mencapai kebahagian dunia dan akhirat. ${ }^{1}$ Alquran banyak mengemukakan pokok-pokok, prinsip-prinsip serta aturan dalam kehidupan, baik hubungan antara manusia dengan sang Khaliq-Nya maupun hubungan antara sesama manusia. Kandungan dan isi dari Alquran tersebut dapat dijadikan bukti bahwa Alquran adalah kitab yang berwawasan luas, karena ayat-ayatnya menghimpun seluruh persoalan yang ada di alam semesta ini. ${ }^{2}$

Sebagai sumber pokok ajaran Islam, Alquran tiada henti-hentinya dikaji secara terus menerus, sehingga muncul ungkapan bahwa mempelajari Alquran adalah sebuah kewajiban. ${ }^{3}$ Kemudian menjadikan Alquran sebagai pedoman hidup, maka perlu pemahaman atau penjelasan yang benar, tetapi untuk mencapai pemahaman yang benar itu tidaklah mudah, sebab diperlukan suatu penafsiran.

Ilmu tafsir ialah ilmu untuk memahami tentang Alquran al-Karim yang diturunkan kepada Muhammad dari segala aspek penjelasan maknanya, pengistinbatan

${ }^{1}$ Rusydi, Ulumul Qur'an I, (Padang: IAIN-IB Press, 1999), hlm. 15

${ }^{2}$ Yusuf al-Qardhawi, Berinteraksi dengan alQur'an, Penerjemah Abdul Hayy al-Khattani, (Jakarta: Gema Insani Press, 1999), hlm. 14

${ }^{3}$ M. Quraish Shihab, Membumikan al-Qur'an,

Fungsi Peranan Wabyu dalam Kebidupan Masyarakat,(Bandung: Mizan, 1997), hlm. 33 (pengambilan), hukum dan hikmahnya. ${ }^{4}$ Secara umum Islam berpandangan bahwa kajian terkait Ilmu Tafsir merupakan salah satu ilmu yang paling mulia dan paling baik. Hal ini dapat di pahami dari perintah Allah SWT untuk merenungkan dan memikirkan kandungan makna-makna Alquran sebagai petunjuk keselamatan dan kebahagiaan dunia dan akhirat.

Adapun kajian ilmu tafsir berkaitan dengan metode, pendekatan, dan corak merupakan suatu pokok bahasan terpenting untuk mencapai tujuan yang telah ditetapkan. Dengan demikian pembicaraan mengenai penafsiran ayat-ayat Alquran tidaklah terlepas dari suatu metode, pendekatan dan corak yang terdapat dalam kajian tafsir. Sebab ketika para penafsir ingin menggali dan memahami ayat-ayat Alquran tersebut perlu menguasai hal demikian ketika memahami kandungan ayat-ayat Alquran secara mendalam. Seiring dengan berkembangnya zaman saat ini maka perlulah penguasaan terhadap metode, pendekatan dan corak tafsir Alquran. Sebab apabila tidak menguasai hal tersebut, sulit digambarkan suatu penafsiran itu terbebas dari kejanggalan maupun kekeliruan. ${ }^{5}$ Dalam pembahasan kali ini penulis akan mencoba membahas tentang metode, pendekatan, dan corak tafsir Alquran.

\section{EPISTEMOLOGI TAFSIR}

\section{A. Metode Tafsir}

Metode berasal dari bahasa Yunani methodos berarti cara atau jalan. Istilah bahasa Inggris dari kata metode adalah

\footnotetext{
4Jalaludin Abd al-Rahman al-Suyuthi, AlItqan fi Ulum al-Qur'an, (Beirut: Dar al-Ma'rifah, 1978), Jil. II, hlm. 222-223

${ }^{5}$ Abd Muin Salim, Metodologi Ilmu Tafsir, (Yogyakarta: Teras, 2005), hlm. 137
} 
method kemudian bangsa Arab menerjemahkannya dengan kata thariqat dan manbaj. Sementara dalam bahasa Indonesia metode adalah suatu cara yang tersusun secara teratur dan terpikir baikbaik dalam mencapai suatu yang dimaksud; cara kerja yang bersistem untuk mendapatkan atau memudahkan pelaksanaan suatu kegiatan guna mencapai suatu yang ditentukan. ${ }^{6}$ Dapat disimpulkan bahwa metode adalah suatu cara yang teratur dan terpikirkan secara baik-baik untuk mencapai kepada suatu pemahaman yang benar tentang apa yang dimaksudkan oleh Allah SWT di dalam ayat-ayat Alquran yang di turunkan-Nya kepada nabi Muhammad SAW.

Adapun yang dimaksud dengan metodologi tafsir adalah ilmu tentang metode menafsirkan Alquran. Dengan kedua istilah tersebut dapat dibedakan, yakni metode tafsir adalah cara-cara menafsirkan Alquran sedangkan metodologi tafsir adalah ilmu mengenai cara tersebut atau pembahasan ilmiah tentang metode-metode penafsiran Alquran. $^{7}$

Jadi, dalam pembahasan mengenai metode tafsir ini terdapat beberapa metode penafsiran Alquran yang masih umum digunakan oleh para ulama tafsir. Sebagaimana 'Abd al-Hayy al-Farmawi menyebutkan bahwa terdapat empat macam metode penafsiran Alquran, yaitu; metode tafsir tablili, metode tafsir Ijmali, metode tafsir maudbu'i, metode tafsir Muqaran. Penulis akan mencoba membahas

${ }^{6}$ Nashruddin Baidan, Metode Penafsiran AlQur'an, (Yogyakarta: Pustaka Pelajar, 2011), hlm. 54

${ }^{7}$ Ibid, hlm. 55 keseluruhan metode tersebut sebagai berikut: ${ }^{8}$

1. Metode Tablili (Analitis)

Secara harfiah tablili berarti lepas atau terurai. ${ }^{9}$ Maksud dari metode tafsir tablili adalah suatu metode menafsirkan ayat-ayat Alquran secara detail, rinci, jelas atau metode penafsiran ayat-ayat Alquran dilakukan dengan cara memaparkan dan mendeskripsikan makna-makna yang terkandung dalam ayat-ayat Alquran dari berbagai segi dan mengikuti urutan yang terdapat dalam mushaf itu sendiri dan mengandung analisis di dalamnya ketika menafsirkan ayat-ayat Alquran. ${ }^{10}$

Penjelasan terkait makna-makna ayat tersebut bias menjelaskan makna kosakata, munasabah ayat maupun surat, susunan kalimatnya, asbab al-nuzul dan tidak lupa pula berbagai pendapatpendapat para sahabat, tabi'in maupun pendapat mufasir lainnya.

Dalam metode tafsir tabliti ini terdapat suatu kecenderungan para penafsir ketika hendak menafsirkan suatu ayat, yakni berupa al-tafsir bi alma'tsur, al-tafsir bi al-ra'yi, al- tafsir al-shufi, al-tafsir al-falsafi, al-tafsir al-adabi alijtima'iy, al-tafsir al-fighi, al-tafsir al-'ilmi. ${ }^{11}$ Adapun contoh kitab-kitab tafsir yang menggunakan metode tafsir tablili adalah; Kitab Jami' al-Bayan fi Tafsir alQur'an karya Ibnu Jarir al-Thabari (w.

${ }^{8} \mathrm{Abd}$ al-Hayy al-Farmawi, Metode Tafsir Maudhu'iy, Suatu Pengantar, Terj. Suryan A. Jamrah, judul asli, Al-Bidayah fi al-Tafsir al-Maudhu'iy: Dirasah Manhajiah Mawdhu'iyah, (Jakarta: Raja Grafindo Persada, 1994), hlm. 7

${ }^{9}$ Muhammad Amin Suma, Ulumul Qur'an, (Jakarta: Rajawali Pers, 2013), hlm. 379

${ }^{10}$ Abd Muin Salim, Metodologi Ilmu Tafsir, hlm.

41

${ }^{11}$ Ibid, hlm. 42 
$310 \mathrm{H} / 922 \mathrm{M})$, terdapat 15 jilid dengan jumlah halaman sekitar 7125, Kitab Tafsir al-Qur'an al-'Az̧im karangan alHafizh Imam al-Din Abi al-Fida' Isma'il bin Katsir al-Quraisyi al-Dimasyqi (w. $774 \mathrm{H} / 1343 \mathrm{M}$ ), kitabnya berjumlah 4 jilid dengan sekitar 2414 halaman (termasuk 58 halaman sisipan ilmu tafsir pada jilid terakhir) dan Kitab Adbwa' alBayanfi Idhab al-Qur'an bi al-Qur'an disusun oleh Muhammad al-Amin bin Muhammad al-Mukhtar al-Jakani alSyanqithi dalam 10 jilid dengan 6771 halaman. ${ }^{12}$

Kemudian setelah penjelasan mengenai pengertian dan beberapa kitab tafsir yang menggunakan metode tafsir tablili ini, maka metode tafsir tablili terdapat beberapa kelebihan dan kekurangan dalam menafsirkan ayat Alquran. Di antara kelebihan metode ini adalah mempunyai ruang lingkup pembahasan yang luas ketika memahami Alquran dan mampu memuat berbagai ide maupun gagasan dalam menafsirkan ayat-ayat Alquran.

Adapun kekurangan dari metode tablili ini adalah (1) membuat petunjuk Alquran bersifat parsial atau terpecahpecah, sehingga seakan-akan terlihat bahwa Alquran memberikan pedoman secara tidak utuh, tidak mendalam dan tidak pula konsisten sebab penafsiran yang diberikan pada suatu ayat berbeda dari penafsiran yang diberikan pada ayat-ayat lain yang sama dengannya. Dengan terjadinya perbedaan tersebut, disebabkan kurangnya memperhatikan ayat-ayat lain yang mirip atau sama

\footnotetext{
${ }^{12}$ Muhammad Amin Suma, Ulumul Qur'an, (Jakarta: Rajawali Pers, 2013), hlm. 380
}

dengannya; ${ }^{13}$ (2) Menggunakan penafsiran secara subjektif, sehingga dapat memberikan peluang yang luas bagi mufasir untuk menyampaikan ide-ide dan pemikirannya; ${ }^{14}$ (3) masuknya pemikiran israiliyat, dan biasanya bersifat kisah-kisah ataupun cerita-cerita.

\section{Metode Tafsir Ijmali (Global)}

Metode tafsir ijmali adalah memahami dan menjelaskan maknamakna yang terkandung dalam ayat-ayat Alquran secara ringkas, umum dan menggunakan bahasa yang mudah dimengerti maupun gaya bahasa yang populer digunakan kemudian juga enak ketika membacanya. Sistematikanya mengikuti urutan surah Alquran sehingga makna-maknanya pun saling keterkaitan. $^{15}$ Kitab-kitab tafsir yang termasuk dalam metode tafsir global, di antaranya; Tafsir al-Jalalain karangan Jalaluddin al-Suyuthiy, kitab Tafsir alQur'an al-Karim karya Muhammad Farid Wajdi dan lain-lain. ${ }^{16}$

Kemudian dalam metode tafsir global ini terdapat kelebihan dan kekurangan, di antara kelebihannya adalah (a) Metode tafsir ijmali ini merupakan metode yang lebih praktis, ringkas dan mudah untuk dipahami. Sehingga pemahaman terhadap Alquran nya pun tidak bertele-tele; (b) Bebas dari pemahaman israiliyat, maksudnya tafsir ijmali ini relatif murni, asli sehingga terbebas dari pemikiran-pemikiran

${ }^{13}$ Nashruddin Baidan, Metodologi Penafsiran Al-Qur'an, (Yogyakarta: Pustaka Pelajar, 2012), hlm. 53

${ }^{14}$ Ibid, hlm. 57

15Islah Gusmian, Khazanah Tafsir Indonesia dari Hermeneutika bingga Ideologi, (Jakarta Selatan: Khazanah Pustaka Keilmuan, 2003), h. 114 ${ }^{16}$ Ibid. 
israiliyat; (c) Penafsiran menggunakan metode tafsir Ijmali tersebut akan akrab dengan bahasa Alquran, berarti tafsir ijmali akan terasa sangat singkat dan padat sehingga para pembaca tidak merasakan kalau dia telah membaca suatu kitab tafsir.

Selain kelebihan dari tafsir ijmali juga terdapat beberapa kekurangan dari metode tafsir tersebut adalah dapat menjadikan petunjuk Alquran bersifat parsial dan metode ini tidak terdapat ruangan untuk mengemukakan ataupun menjelaskan analisis yang memadai. ${ }^{17}$

\section{Metode Tafsir Mudhu'i (Tematik)}

Maudhu'i secara bahasa berasal dari kata وضع- يضع -وضعا- موضع : yang berarti menaruh, meletakkan sesuatu. ${ }^{18}$ Sedangkan maudhu'i yang dimaksud adalah yang dibicarakan, judul atau topik, sehingga tafsir maudhu'i berarti penjelasan ayat-ayat Alquran mengenai satu judul atau topik pembahasan tertentu. Jadi, metode tafsir maudhu'i adalah menafsirkan ayat-ayat Alquran tidak berdasarkan atas urutan ayat dan surah yang terdapat dalam mushaf, tetapi berdasarkan topik atau masalah yang akan dikaji. ${ }^{19}$ Definisi lain tentang tafsir maudhu'i yang dikemukakan oleh Musthafa Muslim yaitu:

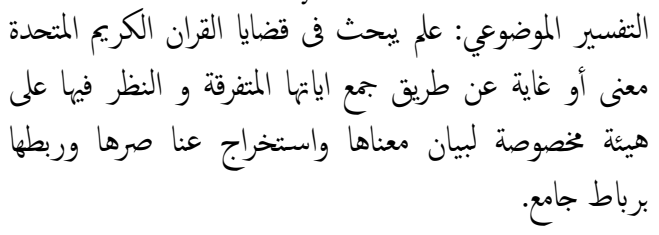

\footnotetext{
${ }^{17}$ Nashruddin Baidan, Metodologi Penafsiran Al-Qur'an, hlm. 22

${ }^{18}$ Mahmud Yunus, Kamus Arab-Indonesia, (Jakarta: PT Hidakarya Agung, 1989), hlm. 501

${ }^{19}$ Kadar M. Yusuf, Studi al-Qur'an, Jakarta: Amzah, 2014), hlm.139
}

"Tafsir yang membahas tentang masalabmasalah Alquran al-Karim yang memiliki kesatuan makna atau tujuan dengan cara menghimpun ayat-ayatnya yang terpisah-pisah untuk melakukan penalaran terbadap isi kandungannya menurut cara-cara tertentu guna menjelaskan makna-maknanya dan mengeluarkan unsur-unsurnya serta menghungbubungkannya antara yang satu dengan yang lain dengan kolerasi yang bersifat konprehensif. 20

Adapun ciri-ciri metode ini adalah lebih menonjolkan tema, judul, atau topik pembahasan. Kemudian, tematema yang dipilih akan dikaji secara tuntas dari berbagai aspek sesuai dengan petunjuk dalam ayat-ayat yang akan ditafsirkan. Masalah-masalah yang ada harus dikaji secara tuntas dan menyeluruh agar mendapatkan sebuah solusi dari permasalahan tersebut. $^{21}$ Dalam metode tafsir maudhu'i terdapat beberapa kitab tafsir yang memakai metode ini adalah; kitab al-Tafsir alWadhib karya Muhammad Mahmud alHija'i dan kitab al-Mar'ah fi al-Qur'an karya 'Abbas Mahmud al-Aqqad. Metode ini terdapat langkah-langkah yang harus ditempuh oleh mufasir, di antaranya sebagaimana yang dikatakan oleh al-Farmawi adalah sebagai berikut:

a. Menentukan atau menetapkan masalah atau tema yang akan dibahas.

b. Mengumpulkan atau menghimpun ayat-ayat yang berkaitan dengan judul, sehingga sesuai dengan kronologi urutan turunnya ayat tersebut.

20Zulheldi, 6 Langkah Metode Tafsir Muadhu'i, (Jakarta: PT Raja Grafindo Persada, 2017), hlm. 29

${ }^{21}$ Nashruddin Baidan, Metodologi Penafsiran AlQur'an.,hlm. 151 
c. Menelusuri latar belakang turunnya ayat-ayat yang telah di himpun.

d. Meneliti dengan serius terhadap seluruh kata atau kalimat yang digunakan dalam ayat tersebut, yang paling utama mengenai kosakata yang menjadi pokok permasalahan di dalam ayat itu. Kemudian mengkajinya dari segala aspek yang berhubungan dengannya.

e. Membahas ataupun mengkaji pemahaman terhadap ayat-ayat itu dari berbagai macam pemahaman aliran maupun pendapat para mufasir, baik mufasir klasik maupun kontemporer.

f. Terakhir dikaji secara tuntas dan seksama dengan menggunakan penalaran atau pemikiran yang objektif melalui kaidah tafsir, didukung oleh fakta (bila ada) dan argumen-argumen dari Alquran, hadis, dan fakta sejarah yang bisa ditemukan. ${ }^{22}$

Metode maudhu'i ini memiliki cakupan yang sangat luas, sama halnya dengan metode-metode yang lain. Metode ini juga tidak luput dari kelebihan dan kekurangan. Di antara kelebihan tafsir maudhu'i adalah:

1) Dapat menjawab tantangan zaman, berarti Penafsiran dengan metode ini mampu mengatasi perkembangan zaman yang selalu berubah dan berkembang. Sehingga setiap permasalahan yang muncul dapat dicari sumbernya melalui metode tafsir tematik.

2) Praktis dan sistematis, maksudnya metode tematik ini disusun secara praktis dan sistematis dalam memecahkan permasalahan. Metode

${ }^{22}$ Ibid, hlm. 152-153 ini sangat cocok dengan kehidupan ummat yang memiliki mobilitas yang sangat tinggi, karena mereka tidak memiliki waktu untuk membaca kitab-kitab tafsir yang besar. Disamping itu metode ini dapat menghemat waktu, mengefektifkannya dan mengefesienkannya.

3) Dinamis, maksud dari metode ini menimbulkan kesan bahwa Alquran selalu mengayomi dan membimbing ummat. Dengan demikian Alquran selalu aktual dan tidak ketinggalan zaman.

4) Membuat pemahaman menjadi utuh, sehingga dengan ditetapkannya juduljudul pembahasan yang akan dikaji, membuat pembahasan menjadi sempurna dan utuh. ${ }^{23}$

Disamping terdapat beberapa kelebihan tafsir maudhu'i, ternyata juga memiliki beberapa kekurangan, di antara beberapa kekurangannya adalah:

1) Memenggal ayat-ayat Alquran, maksudnya adalah metode ini mengambil satu kasus yang terdapat dalam satu ayat atau lebih yang mengandung berbagai macam permasalahan, misanya shalat, zakat dan lain sebagainya. Cara ini terkadang dipandang oleh sebagian ulama (tekstualisme) dengan kurang sopan, namun jika tidak membawa kerusakan atau kesalahan dalam penafsiran hal ini tidak menjadi masalah.

2) Membatasi pemahaman ayat, dengan adanya penetapan judul dalam penafsiran, maka dengan sendirinya membuat suatu permasalahan jadi

\footnotetext{
23Samsurohman, Pengantar Ilmu Tafsir, (Jakarta: Amzah, 2014), hlm. 132-133
} 
terbatas (sesuai dengan topic itu saja), padahal jika dilihat pada ketentuan Alquran, tidak mungkin ayat-ayat yang ada padanya mempunyai keterbatasan itu tidak mencakup seluruh makna yang dimaksud. ${ }^{24}$

4. Metode Tafsir Muqaran (Perbandingan)

Secara etimologi muqaran berasal dari kata قارن-يقارن-مقارنة berarti perbandingan (komparatif), menyatukan atau menggandengkan. ${ }^{25}$ Metode tafsir muqaran adalah pertama; membandingkan nash ayat-ayat Alquran yang memiliki persamaan atau kemiripan redaksi yang beragam dalam dua kasus atau lebih dan memiliki redaksi yang berbeda pada satu kasus yang sama; kedua, membandingkan ayat-ayat Alquran dengan hadist Nabi SAW yang pada lahirnya terlihat bertentangan antara keduanya; ketiga, membandingkan berbagai pendapat mufasir dalam menafsirkan ayat Alquran. $^{26}$

Kemudian M. Quraish Shihab mengungkapkan bahwa tafsir muqaran adalah membandingkan ayat-ayat Alquran satu dengan yang lainnya yaitu ayat-ayat yang memiliki persamaan dan kemiripan redaksi dalam dua kasus atau masalah yang berbeda atau lebih. Dan yang lainnya itu memiliki redaksi yang berbeda bagi masalah atau kasus yang sama atau diduga sama, kemudian membandingkan ayat-ayat Alquran dengan hadis Nabi Muhammad SAW yang kelihatan bertentangan, dan yang terakhir membandingkan berbagai

\footnotetext{
${ }^{24}$ Ibid, hlm. 135

${ }^{25}$ Rusydi, 'Ulum al-Qur'an II, hlm. 88

${ }^{26}$ Nashruddin Baidan, Metodologi Penafsiran Al-Qur'an,hlm. 65
}

pendapat ulama tafsir berkaitan dengan penafsiran Alquran. ${ }^{27}$ Dari penjelasan yang dikemukakan M. Quraish Shihab di atas, bahwa defenisinya tersebut lebih umum serta mencakup aspek dalam menafsirkan ayat Alquran.

Pendapat lain oleh Abd al-Hayy alFarmawiy, metode muqaran adalah mengemukakan penafsiran ayat-ayat Alquran yang ditulis oleh sejumlah mufasir. Di mana seorang penafsir menghimpun sejumlah ayat-ayat Alquran, kemudian ia mengkaji dan meneliti penafsiran sejumlah mufassir mengenai ayat tersebut melalui kitabkitab tafsir mereka, apakah mereka itu penafsir dari generatif salaf maupun khalaf, apakah tafsir bi al-ma'tsur atau bi al-ra'yi. ${ }^{28}$

Berdasarkan defenisi tafsir muqaran yang telah dikemukakan di atas, maka dari segi objek bahasan metode tafsir muqaran ini memiliki beberapa kategori, serta masing-masingnya itu mempunyai langkah-langkah dalam penerapannya, berikut penjelasannya, yaitu:

a. Perbandingan ayat Alquran dengan ayat lain

Adapun langkah-langkah yang digunakan dalam perbandingan ayat Alquran dengan ayat lain adalah sebagai berikut:

1) Menghimpun dan mengumpulkan ayat-ayat Alquran yang redaksinya bermiripan kemudian diketahui mana yang mirip dan yang tidak.

2) Memperbandingkan antara ayat-ayat yang redaksinya itu mirip, yang membicarakan satu kasus yang sama,

\footnotetext{
${ }^{27}$ Rusydi, 'Ulum al-Qur'an II, hlm. 89

${ }^{28}$ A Abd al-Hayy al-Farmawy, Metode Tafsir Maudhu'iy, Suatu Pengantar, hlm. 30
}

Perada: Jurnal Studi Islam Kawasan Melayu, Vol. 3, No. 1, Juni 2020 http://ejournal.stainkepri.ac.id/index.php/perada 
atau dua kasus yang berbeda dalam satu redaksi yang sama.

3) Menganalisis perbedaan yang terkandung di dalam berbagai redaksi yang mirip, baik perbedaan mengenai konotasi ayat, maupun redaksinya seperti berbeda dalam menggunakan kata dan susunannya dalam ayat dan sebagainya.

4) Memperbandingkan antara berbagai pendapat para ulama tafsir tentang ayat yang dijadikan sebagai objek bahasan. ${ }^{29}$

b. Perbandingan Ayat Alquran dengan Hadis

Terkait dengan langkah-langkah yang dapat ditempuh pada perbandingan ayat Alquran dengan hadis nabi Muhammad SAW yaitu;

1) Mengidentifikasi dan menghimpun ayat-ayat yang pada lahirnya tampak bertentangan dengan hadis-hadis Nabi SAW baik ayat tersebut memiliki kemiripan redaksi dengan ayat-ayat yang lain ataupun tidak.

2) Memperbandingkan dan menganalisa pertentangan yang ditemukan di dalam kedua teks ayat dan hadis tersebut.

3) Membandingkan antara berbagai pendapat ulama tafsir dalam menafsirkan ayat Alquran dengan hadis tersebut.

c. Perbandingan Pendapat Ulama Tafsir

Adapun langkah-langkah yang harus ditempuh dalam menerapkan metode perbandingan pendapat ulama tafsir adalah sebagai berikut:

1) Menghimpun sejumlah ayat yang dijadikan sebagai objek studi tanpa menoleh terhadap redaksinya, mempunyai kemiripan atau tidak. ${ }^{30}$

2) Melacak atau menelusuri berbagai pendapat ulama tafsir dalam menafsirkan ayat-ayat Alquran tersebut.

3) Membandingkan dan menganalisa pendapat-pendapat mereka agar mendapatkan informasi yang berkenaan dengan identitas dan pola berpikir dari masing-masing mufassir, serta kecenderungan dan aliran yang mereka perpegangi. ${ }^{31}$

Metode tafsir muqaran merupakan salah satu metode yang digunakan dalam penafsiran ayat-ayat Alquran. Metode ini memiliki cakupan sangat luas karena hal demikian metode muqaran ini tidak luput dari kelebihan dan kekurangan. Di antara kelebihan metode ini adalah sebagai berikut:

a. Memberikan wawasan penafsiran yang relatif lebih luas kepada pembaca apabila dibandingkan dengan metode-metode lain. Sebab dalam penafsiran terlihat bahwa ayatayat Alquran itu dapat ditinjau dari berbagai disiplin ilmu pengetahuan sesuai keahlian mufasir, sehingga terasa bahwa Alquran itu tidaklah sempit, melainkan sangat luas dan dapat menampung berbagai ide maupun pendapat.

b. Selalu bersikap toleran terhadap berbagai pendapat orang lain yang terkadang jauh berbeda dari pendapat seseorang dan tidak mustahil ada yang bertentangan atau kontradiktif.

c. Metode muqaran ini sangat berguna bagi masyarakat yang ingin

${ }^{30}$ Ibid, hlm. 93 dan 101
${ }^{31}$ Ibid. 
mengetahui berbagai pendapat tentang suatu ayat.

d. Metode komparatif ini mendorong mufasir untuk mengkaji berbagai ayat dan hadis-hadis serta pendapat ulama tafsir lain.. ${ }^{32}$

Kemudian di antara kekurangan dari metode muqaran ialah sebagai berikut: ${ }^{33}$

a. Penafsiran menggunakan metode komparatif ini tidak bisa diberikan kepada para pemula, seperti mereka yang sedang belajar pada tingkat sekolah menengah ke bawah.

b. Metode ini belum bisa diandalkan untuk menjawab persoalan-persoalan sosial yang tumbuh ditengah-tengah masyarakat. Hal ini disebabkan metode tafsir muqaran ini lebih mengutamakan perbandingan dari pada pemecahan masalah. ${ }^{34}$

\section{B. Metode Hermeneutika}

1. Pengertian Hermeneutika

Hermeneutika secara bahasa berasal dari bahasa Yunani, yakni hermeneuein berarti menjelaskan. Sedangkan dalam bahasa Jerman kata tersebut adalah hermeneutik dan dalam bahasa Inggris menjadi bermeneutics. Ada juga yang berpendapat bahwa istilah hermeneutika pada awalnya merujuk pada nama dewa Yunani kuno yakni hermes, maksudnya seseorang yang di utus dan bertugas untuk menyampaikan pesan dari para dewa dan menjelaskan maksudnya kepada manusia. Para pakar menilai sementara bahwa yang dijelaskan oleh hermes itu mencakup tiga bentuk, yaitu:

\footnotetext{
${ }^{32}$ Rusydi, 'Ulum al-Qur'an II, hlm. 95-97

${ }^{33}$ Nashruddin Baidan, Metodologi Penafsiran Al-Qur'an, hlm. 143-144

${ }^{34}$ Ibid.
}

a. Mengungkapkan yang ada dalam pikiran melalui kata-kata dalam rangka sampai kepada sasaran yang dituju.

b. Menjelaskan secara rasional terkait halhalyang masih belum jelas sehingga maksudnya dapat dipahami dengan jelas.

c. Menerjemahkan dengan menggunakan bahasa yang mudah untuk dipahami oleh sasaran.

Zygmunt Bauman mendefenisikan hermeneutika adalah sebagai upaya menjelaskan atau menelusuri pesan dan maksud dasar dari perkataan atau tulisan yang tidak jelas, samar dan kontradiksi sehingga menimbulkan keraguan dan kejanggalan bagi para pendengar dan pembaca. $^{35}$ Defenisi hermeneutik juga dikemukakan oleh Franz-Peter Burkard adalah seni menafsirkan teks dengan arti yang lebih luas, jadi hermeneutika adalah refleksi teoritis tentang metode-metode dan syarat-syarat pemahaman. ${ }^{36}$

M. Quraish Shihab mendefenisikan hermeneutika adalah suatu alat yang digunakan terhadap suatu teks dalam menjelaskan, memahami dan menganalisis maksudnya serta memperlihatkan nilai-nilai yang terkandung di dalamnya. Kemudian bisa dikatakan dengan suatu cara yang harus ditempuh seseorang yang hendak memahami terhadap suatu teks, baik secara nyata, maupun tidak jelas bahkan tersembunyi disebabkan dengan perjalanan sejarah atau terpengaruhnya kepercayaan. ${ }^{37}$

${ }^{35}$ Yayan Rahtikawati, Dadan Rusmana, Metodologi Tafsir al-Quran Strukturalisme, Semantik, Semiotik, \& Hermeneutik, (Jawa Barat: Pustaka Setia, 2013), hlm. 447

${ }^{36}$ Sahiron Syamsuddin, Hermeneutika Dan Pengembangan Ulumul Qur'an, (Yogyakarta: Nawesea Press, 2017), hlm.14

${ }^{37}$ M. Quraish Shihab, Kaidab Tafsir, (Tangerang: Lentera Hati, 2013), hlm. 401 
Dalam hal ini hermeneutika di bagi dalam tiga bagian adalah sebagai berikut:

a. Hermeneutika teori, maksudnya suatu teori yang fokus bahasannya pada metodologi.

b. Hermeneutika filsafat adalah suatu penafsiran yang mempunyai proses produksi makna yang baru bukan reproduksi makna awal.

c. Hermeneutika kritis, merupakan aliran yang menolak asumsi-asumsi idealis atau pembahasannya itu terkait upaya membuka penyebab dalam pemutarbalikan pemahaman.

Hermeneutika juga bisa diartikan sebagai tiga hal, yaitu: pertama, mengungkapkan pemikiran seseorang dengan kata-kata, menerjemahkan dan bertindak sebagai penafsir. Kedua, memiliki suatu usaha untuk memalingkan atau mengalihkan dari suatu bahasa asing yang maknanya itu gelap dan tidak diketahui ke dalam bahasa lain yang dapat dimengerti dan dipahami oleh pembaca. Ketiga, pemindahan terhadap ungkapan yang kurang jelas, dan dirubah kepada bentuk yang lebih jelas. ${ }^{38}$

\section{Sejarah Hermeneutika}

Hermeneutika merupakan istilah yang familiar di dengar dan tidak hanya berkembang di dunia barat, tetapi ia meluas dan menembus pada agama dan budaya. Sehingga hermeneutika ini tidak terlepas dari pertumbuhan dan perkembangan pemikiran filsafat dan keilmuan lainnya.

\footnotetext{
${ }^{38}$ Umiarso, Hassan Hanafi, Pendekatan Hermeneutik dalam Menghidupkan Tuban, dalam Metodologi Studi Islam, Percikan Pemikiran Tokoh dalam Membumikan Agama, (Yogyakarta: Ar-Ruzz edia, 2013), hlm. 196
}

Mulanya hermeneutik ini banyak digunakan oleh mereka yang memiliki hubungan erat dengan kitab suci Injil ketika menafsirkan kehendak Tuhan kepada manusia. Kemudian kajian terkait dengan hermeneutik ini mulai berkembang pada abad 17 dan 18. Pada abad 20 pembahasan hermeneutika ini semakin berkembang. Dan tidak hanya terkait dengan kitab Suci dan teks-teks klasik saja, melainkan terkait juga dengan ilmu-ilmu lainnya, seperti sejarah, filsafat, kesusasteraan, hukum dan lain-lain yang mencakup dalam ilmu pengetahuan tentang kemanusiaan. Pembahasan hermeneutik ini telah ada dalam tulisan Aristoteles berjudul peri hermenians dan diterjemahkan kepada bahasa latin dengan nama De Interpretation. ${ }^{39}$ Sehingga dalam hal ini hermeneutika dari segi sejarahnya dibagi menjadi tiga tahap/fase, yakni:

1) Hermeneutika klasik, yakni lebih berorientasi atau menekankan pada teks, muncul sekitar abad XVII. Tahap ini berpendapat bahwa sebagai penafsir dapat mengetahui tujuan pengarang teks dan substansinya selama menempuh dengan metode yang shahih.

2) Tahap hermeneutika romansis, berawal dari Friedrich Schleiermacher (1768$1834 \mathrm{M}$ ), yang mana lebih menekankan dan menitikberatkan pada metode dan berguna untuk menghindari dari kesalahpahaman. Dalam hal ini sangat berpengaruh terhadap pemikir-pemikir hermeneutik setalahnya, baik setuju maupun tidak setuju dengan alirannya. Ia dinilai telah mengalihkan hermeneutika dari penafsiran teks

\footnotetext{
${ }^{39}$ Sahiron Syamsuddin, Hermeneutika Alqur'an Mazhab Yogya, (Yogyakarta: Islamika, 2003), hlm. 53-54
} 
keagamaan secara teks kepada berbagai teks lainnya.

3) Hermeneutika filosofis. Pembahasan ini lebih kepada hal-hal yang berkaitan dengan hakikat pemahaman dan kondisi penemuannya tanpa menjelaskan metode tentang makna pemahaman.

Tahun 1980-an muncul hermeneutik Alquran feminis yang dikemukakan oleh Riffat Hassan. Dan sepuluh tahun kemudian muncullah hermeneutic Alquran tentang pluralism religious dan pembebasan berdasarkan dengan pengalaman sosial penafsir. ${ }^{40}$

\section{Aliran Hermeneutika}

Pembagian tentang aliran dapat mempermudah dalam memahami berbagai macam pemikiran dengan memperhatikan keunikan masing-masing aliran yang diperpegangi. Maka dalam satu aliran saja bias ditemukan berbagai macam pemikiran yang saling melengkapi antara satu dengan lainnya. Sehingga setiap pemikir mempunyai ciri khas tersendiri. Dalam hal ini pemaknaan teks terhadap obyek penafsiran aliran hermeneutika ini dibagi kepada tiga aliran utama.

Pertama, aliran obyektivis, yakni aliran yang lebih menitikberatkan kepada pencarian makna asal dari obyek penafsiran. Jadi, penafsiran adalah suatu upaya mengembalikan apa yang dimaksud oleh pencipta teks. Dalam pemahaman dan penafsiran aliran ini, para penafsir hanya berusaha memaparkan atau menjelaskan kembali apa yang dimaksud oleh pengarang teks. Agar penafsir bisa mencari tahu maksud dari pengarang, maka harus dilakukan sebuah analisa bahasa teks dan analisa diluar kebahasaan. hlm. 254
Kedua, aliran subyektivis, yakni sebuah aliran yang lebih menekankan pada peran pembaca atau penafsir dalam pemaknaan teks. Biasa disebut dengan "reader-cantered hermeneutics".

Ketiga, aliran obyektivis-cumsubyektivis, yakni aliran berada di tengahtengah, dalam hal pemaknaan terhadap teks yang ditafsirkan, sehingga aliran ini berusaha mencari tahu kembali makna orisinil/historis dari satu sisi dan pengembangan makna teks pada masa dimana teks itu ditafsirkan. Atau aliran ini memberi keseimbangan antara pencarian makna asal teks dan peran bagi pembaca dalam penafsiran. ${ }^{41}$

\section{Pendekatan dalam Tafsir Alquran}

Pendekatan adalah merupakan sebagai titik keberangkatan dari prosesnya tafsir. Sebab dengan adanya pendekatan tafsir yang sama bisa saja muncul corak tafsir yang berbeda-beda. ${ }^{42}$ Kemudian Abuddin Nata menjelaskan bahwa yang dimaksud dengan pendekatan adalah suatu proses atau cara pandang yang digunakan untuk menjelaskan suatu data yang dihasilkan dalam penelitian. ${ }^{43}$ Adapun yang dimaksud dengan pendekatan disini adalah cara pandang atau paradigma yang terdapat di dalam suatu bidang ilmu dan selanjutnya digunakan atau diterapkan dalam memahaminya. Dalam hal ini untuk mengetahui lebih lanjut, penulis akan mencoba menguraikan secara komprehensif tentang pendekatan-

\footnotetext{
${ }^{41}$ Sahiron Syamsuddin, Hermeneutika Dan Pengembangan Ulumul Qur'an, hlm. 45-50 hlm. 247

${ }^{42}$ Islah Gusmian, Khazanah Tafsir Indonesia,

${ }^{43}$ Abuddin Nata, Metodologi Studi Islam, (Jakarta: Raja Grafindo Persada, 1998), hlm. 142
} 
pendekatan dalam tafsir Alquran, di antaranya sebagai berikut.

\section{Pendekatan Tekstual}

Maksudnya adalah suatu pendekatan dalam menafsirkan Alquran lebih menekankan pada teks dalam dirinya. Ahsin Muhammad misalnya, menegaskan bahwa kontekstualisasi pemahaman Alquran merupakan suatu upaya penafsir dalam memahami ayat Alquran bukan melalui teks tetapi dilihat dari konteks dengan melihat faktorfaktor, seperti situasi dan kondisi dimana ayat Alquran diturunkan, sehingga sebagai seorang penafsir harus mempunyai cara berfikir luas.

Jadi, kontekstualitas dalam pendekatan tekstual ini cenderung bersifat kearaban, sebab Alquran turun pada masyarakat Arab. Dengan demikian, suatu tafsir yang menggunakan pendekatan tekstual, biasanya analisisnya itu lebih cenderung bergerak dari teks kepada konteks dan bersifat lebih kearaban. Adapun buku tafsir Indonesia yang menggunakan objek ini, secara umum menekankan perspektif tekstualreflektif, seperti Kitab Tafsir al-Mishbah, Alquran dan Tafsirnya.

\section{Pendekatan Kontekstual}

Pendekatan kontekstual adalah pendekatan yang lebih berorientasi pada konteks pembaca atau penafsir teks Alquran. Pendekatan ini, kontekstualitas dalam pendekatan tekstual, yaitu dengan latar belakang sosial-historis, yang mana teks muncul dan dikelolah menjadi penting. Sehingga dalam pendekatan ini harus ditarik dalam konteks pembaca (penafsir) dimana ia hidup maupun berada saat itu, dengan pengalaman budaya, sejarah dan sosialnya sendiri. ${ }^{44}$

Mengenai konteks tafsir yang menyajikan tematik ada beberapa, namun yang muncul dalam bentuk realitas sosial, meskipun belum menemukan bentuk kontekstualnya secara kuat. Bisa dilihat dalam Tafsir Kebencian Argumen Kesetaraan Gender, Tafsir bil Ra'yi dan Tafsir Tematik Alquran tentang Hubungan Antar Umat Beragama.

Tafsir tematik terkait Hubungan Antar Umat beragama dalam hal tertentu bisa dikatakan sebagai model pendekatan kontekstual. Sebagaimana Syafi'i Ma'rif menjelaskan bahwa buku ini merupakan bentuk kegelisahan sekaligus sebagai sumbangan bangsa Indonesia ketika menghadapi hubungan antar umat beragama. Sebab banyak nyawa yang terkorbankan, kehormatan dan harta benda hilang begitu saja demi menyelamatkan agama.

Secara pengetahuan menyadari bahwa Indonesia adalah sebuah bangsa yang majemuk. Terhadap perbedaan dan keragaman agama itu merupakan suatu kenyataan maupun niscaya yang tidak ada penyesalan di dalamnya. Maka yang harus dibangun saat ini dalam buku ini adalah kesadaran dari setiap pemeluk agama masing-masing untuk memahami ajaran-ajaran moral kitab suci agamanya kembali. $^{45}$

\section{Pendekatan Bahasa (Sastra)}

Alquran menggunakan bahasa Arab, maka perlu diketahui untuk memahami isi kandungan Alquran diperlukan pemahaman dan hlm. 248

${ }^{44}$ Islah Gusmian, Khazanah Tafsir Indonesia,

${ }^{45}$ Ibid, hlm. 250 
pengetahuan tentang bahasa Arab. Dan untuk mengkaji sekaligus memahami arti suatu kata dalam rangkaian redaksi ayat, seseorang untuk terlebih dahulu meneliti pengertian apa saja yang dikandung maupun terdapat dalam kata tersebut. Lalu menetapkan arti kata tersebut dengan tepat setelah memperhatikan segala aspek yang berkaitan dengan ayat tersebut. ${ }^{46}$

Yang dimaksud dari pendekatan bahasa adalah dimana seseorang yang ingin menafsirkan Alquran dengan pendekatan bahasa harus mengetahui bahasa yang digunakan Alquran yakni bahasa Arab dengan mengetahui selukbeluknya dahulu, baik terkait dengan nahwu, balaghah dan sastranya. Dengan mengetahui bahasa Alquran, seorang mufasir akan lebih mudah untuk melacak dan mengetahui makna dan susunan kalimat-kalimat Alquran sehingga mampu menjelaskan atau mengungkap makna di balik kalimat tersebut.

\section{Pendekatan Historis}

Maksud dari pendekatan ini adalah memahami ayat-ayat Alquran dengan memperhatikan konteks sejarah turunnya ayat Alquran tersebut yang disebut sebagai asbab al-nuzul. Dengan memahami pendekatan ini seseorang bisa mengetahui hikmah kandungan dari suatu ayat. Sehingga dengan mengetahui kondisi historis ayat tersebut, seorang dapat menggambarkan dan mengenal ketika ayat itu diturunkan dan memberi

${ }^{46}$ M. Quraish Shihab, Membumikan Alquran (Fungsi, dan Peran Wabyu dalam Kebidupan Masyarakat), (Bandung: Mizan), hlm. 105 kemudahan untuk memikirkan apa yang terkandung dalam ayat tersebut. ${ }^{47}$

Sehingga dengan mengetahui asbab al-nuгul adalah cara yang paling penting dan baik dalam memahami pengertian ayat. Kemudian para sahabat yang lebih tahu tentang sebab-sebab turunya ayat maka, pendapatnya itu lebih didahulukan terhadap pengertian dari suatu ayat, dibandingkan dengan sahabat yang tidak mengetahi sebab-sebab turunnya ayat. ${ }^{48}$

\section{Pendekatan Sosio-Historis}

Pendekatan sosio-historis merupakan pendekatan yang sangat penting untuk melihat setiap data, karena segala sesuatu yang ada dalam kehidupan ini tidak ada yang tanpa melalui proses dan tanpa berhubungan dengan masyarakat di lingkungannya termasuk ketika dalam menempuh studi agama pada umumnya dan studi Alquran pada khususnya.

Jadi, maksud dari pendekatan sosiohistoris adalah memahami ayat-ayat Alquran dengan melihat konteks sosiohistorisnya dan setting sosial pada saat dan menjelang ayat Alquran diturunkan ketika dalam mengkaji suatu penafsiran tersebut. ${ }^{49}$

\section{Corak-corak dalam Tafsir Alquran}

Corak penafsiran adalah suatu arah, warna dan kecenderungan pemikiran atau

\footnotetext{
${ }^{47}$ Ahmad Soleh Sakn, "Model Pendekatan Tafsir dalam Kajian Islam”, Jurnal Ilmu Agama, No. 2, Desember 2013

${ }^{48}$ Ibid.

${ }^{49}$ Ulya, Berbagai Pendekatan Dalam Studi AlQur'an; Penggunaan Ilmu-ilmu Sosial, Humaniora, dan Kebahasaan dalam Penafsiran al-Qur'an, (Yogyakarta: Idea Press, 2017), hlm 30
} 
ide yang mendominasi suatu karya tafsir. ${ }^{50}$ Dapat disimpulkan bahwa corak tafsir adalah ragam, jenis dan kekhasan suatu tafsir, dengan pengertian umum corak tafsir adalah kekhususan suatu tafsir yang merupakan dampak dari kecenderungan seorang mufasirdalam menjelaskan maksud ayat-ayat Alquran.Ataupun yang dimaksud dengan corak tafsir adalah ragam dan nuansa khusus yang mewarnai sebuah penafsiran dan merupakan salah satu bentuk ekspresi intelektual seorang mufasir ketika menjelaskan maksud Alquran. Dari segi corak tafsir Alquran terdapat berbagai macam corak penafsiran Alquran ketika para pengkaji tafsir melakukan terhadap penafsiran, di antara corak-corak tafsir Alquran adalah sebagai berikut.

\section{Corak Tafsir falsafi (Filsafat)}

Maksud dari corak ini adalah menafsirkan ayat-ayat Alquran dengan menggunakan logika dan teori-teori filsafat bersifat radikal atau liberal. Munculnya corak penafsiran ini seiring dengan berkembangnya ilmu-ilmu agama dan sains di berbagai wilayah kekuasaan Islam yakni ketika periode penterjemahan di masa Abbasiyah. Pada waktu itu bukubuku filsafat Yunani banyak diterjemahkan dalam bahasa Arab dan saat itu adalah karya Plato dan Aristoteles. ${ }^{51}$

Kemudian dapat diketahui bahwa seiring berkembangnya ilmu-ilmu tersebut, terkhusus mengenai filsafat, terdapat pro dan kontra dikalangan ulama muslimin dalam penafsiran Alquran yang bercorak falsafi. Adapun golongan yang

\footnotetext{
${ }^{50}$ Muhammad Sofyan, Tafsir wal Mufassirun, (Medan: Perdana Publishing, 2015), hlm. 25

${ }^{51}$ Usman, Ilmu Tafsir, (Yogyakarta: Teras, 2009), hlm. 292-294
}

kontra tersebut beranggapan bahwa banyak bertentangan dengan akidah dan agama selain itu ketika dalam menafsirkan Alquran mereka mengesampingkan tata bahasa Arab dan ilmu balaghahnya. Dan ulama yang pro terhadap corak ini beralasan bahwa selama penafsiran itu tidak bertentangan dengan norma-norma dalam Islam, sehingga berusaha menggabungkan antara agama dan filsafat serta menghilangkan pertentangan antara keduanya, maka tidak ada salahnya melakukan penafsiran tersebut. Cara menggabungkan keduanya adalah dengan melakukan takwil terhadap nash-nash yang sesuai dengan teori-teori filsafat. ${ }^{52}$ Adapun tafsir yang menggunakan corak ini adalah; tafsir Mafatib al-Ghaib karya Imam Fakhr al-Din Razi dan Tahafut alTahafut karya Ibnu Rusyd. ${ }^{53}$

\section{Corak Tafsir Fiqhi (Hukum)}

Corak tafsir fiqhi adalah menafsirkan Alquran yang lebih berorientasi kepada ayat-ayat hukum yang terdapat dalam Alquran atau penafsiran ayat-ayat Alquran yang berkaitan dengan masalah-masalah hukum fiqh, sedangkan ayat-ayat yang lain dan tidak memuat hukum-hukum fiqh maka tidak dijadikan sebagai target dalam penafsirannya bahkan cenderung tidak dimuat sama sekali. Corak ini sudah ada sejak masa Rasulullah SAW. Sebab ketika para sahabat kesulitan dalam memahami hukum yang terkandung dalam Alquran tersebut, maka sahabat langsung menanyakan hal itu kepada Nabi dan beliau pun langsung menjawab. Adapun kitab tafsir yang bercorak fighi adalah

\footnotetext{
${ }^{52} \mathrm{Ibid}$.

${ }^{53}$ M. Yudie R. Haryono, Bahasa Politik Alquran: Mencurigai Makna Tersembunyi di Balik Teks, (Bekasi: Gugus Press, 2002), hlm. 159
} 
kitab Abkam al-Qur'an karya al-Jashshash (w. $370 \mathrm{H}$ ) dari golongan Hanafiyah, kitab Abkam al-Qur'an karya Alkiya al-Harasi (w. $504 \mathrm{H}$ ) golongan Syafi'iyyah dan terakhir dari golongan Malikiyyah kitab alJami' li al-Abkam al-Qur'an karya alQurthubi (w. $671 \mathrm{H}) .^{54}$

\section{Corak Tafsir 'Tlmi (Ilmu/Science)}

Tafsir 'ilmi adalah penafsiran ayatayat Alquran dengan melakukan pendekatan ilmiah atau mengkaji ayat-ayat Alquran berorientasi pada teori-teori ilmu pengetahuan. ${ }^{55}$ Ayat-ayat Alquran yang ditafsirkan dalam corak ini adalah ayatayat kauniyah (tentang kealaman). Corak tafsir seperti ini memberi peluang yang luas bagi mufasir dalam mengembangkan ilmu pengetahuannya ataupun berbagai potensi keilmuan yang ada dan akan di bentuk dalam Alquran. Perlu diketahui ketika menggunakan corak penafsiran ini adalah berpegang pada hakikat ilmiah yang dapat dijadikan sebagai rujukan maupun sandaran, tidak memaksakan diri dalam memahami nash dan tidak sembarangan dalam menukil nash dengan suatu makna yang diinginkan kesimpulannya. Tetapi hanya mengambil makna sesuatu dengan pertolongan bahasa dan terkandung dalam ungkapan tanpa ada paksaan dan sesuai dengan hubungan kalimatnya. ${ }^{56}$

Kitab-kitab tafsir yang menggunakan corak penafsiran ini adalah kitab al-Jawabir fi Tafsir al-Qur'an karangan Thanthawi Jawhari (1287-1358 H) terdiri 13 jilid, 26 hlm. 399

54 Muhammad Amin Suma, Ulumul Qur'an,

55 Mohammad Gufron, Rahmawati, Ulumul Qur'an: Praktis dan Mudah, (Yogyakarta: Teras, 2013), h. 195

56 Mohammad Gufron Rahmawati, Ulumul Qur'an, hlm. 196 juz dan 6335 halaman, kitab al-Tafsir alIlmi li al-Ayat al-Kawniyah fi al-Qur'an karya Hanafi Ahmad dan kitab al-Isyarat alIlmiyah fi al-Qur'an al-Karim karya Dr. Muhammad Syawqi al-Fanjari. ${ }^{57}$ Dapat diketahui bahwa corak penafsiran ini muncul seiring dengan berkembang dan kemajuannya ilmu pengetahuan saat ini dan terdapat suatu usaha bagi para pengkaji tafsir untuk memahami ayat-ayat Alquran yang sejalan dengan perkembangan ilmu.

\section{Corak Tafsir Sufi}

Maksudnya adalah penafsiran ayatayat Alquran yang menggunakan pemahaman tasawuf atau beraliran tasawuf. Corak ini dibagi menjadi dua macam adalah; pertama tafsir Sufi alNazhariy adalah tafsir yang disusun oleh ulama-ulama dalam penafsiran ayat-ayat Alquran yang berpegang pada teori-teori tasawuf yang mereka perpegangi dan dikembangkan. Kedua tafsir Sufi al-Isyari berarti penafsiran ayat-ayat Alquran yang berusaha mentakwilkan berdasarkan isyarat-isyarat yang tersembunyi dan hanya diketahui oleh para sufi ketika mereka melaksanakan suluk. ${ }^{58}$

Kemudian di antara kitab-kitab tafsir yang bercorak shufi adalah tafsir al-Qur'an al-Azhim karya Abdullah al-Tustariy (w.283 H), kitab Haqaiq al-tafsir karya al'Alamah al-Sulamiy (w. $412 \mathrm{H}$ ) dan kitab Ara'is al-Bayan fi Haqaiqal-Qur'an karya Imam al-Syiraziy (w. $606 \mathrm{H}$ ).

Para ulama tafsir berpendapat bahwa dalam tafsir bercorak shufi ini banyak terdapat kesalahan dan penyimpangan, hlm. 398

${ }^{57}$ Muhammad Amin Suma, Ulumul Qur'an, ${ }^{58}$ Usman, Ilmu Tafsir, hlm. 288 
maka tafsir ini bisa saja diterima apabila memenuhi syarat-syarat sebagai berikut;

a. Tidak bertentangan dengan makna lahiriyah ayat;

b. Penafsirannya itu dapat dikuatkan dengan dalil syara' yang lainnya;

c. Penafsirannya tidak bertentangan dengan dalil syara' dan akal;

d. Ahli tafsirnya tidaklah menganggap apabila penafsirannya itu merupakan satu-satunya penafsiran yang memang benar, tapi harus mengakui terlebih dahulu makna lahiriyah ayat. $^{59}$

5. Corak Tafsir al-Adabiy al-Ijtima'i (SosialKemasyarakatan)

Al-Adabiy merupakan bentuk mashdar dan kata kerja dari aduba berarti tatakrama dan sopan santun. Sementara kata alIjtima'iy berarti menyatukan sesuatu dan juga dapat diterjemahkan kemasyarakatan. Maka, secara etimologi al-adabi al-ijtima'iy adalah penafsiran yang lebih menekankan kepada sastra budaya dan kemasyarakatan. ${ }^{60}$ Sedangkan secara terminologi corak tafsir adabiy ijtima'iy adalah memahami ayat-ayat Alquran dengan cara menyebutkan ungkapanungkapan Alquran secara teliti lalu menjelaskan makna-makna yang dimaksud oleh Alquran tersebut dengan menggunakan keindahan gaya bahasa sehingga menjadi menarik ketika membacanya. Kemudian para mufasir menghubungkannya nash-nash Alquran yang sedang dikaji sesuai dengan kondisi sosial dan sistem budaya yang ada pada masyarakat. ${ }^{61}$

\footnotetext{
${ }^{59}$ Ibid., hlm. 291

${ }^{60}$ Usman, Ilmu Tafsir, hlm. 298

${ }^{61}$ Islah Gusmian, Khazanah Tafsir Indonesia,
} hlm. 235
Menurut al-Dzahabi yang dimaksud dari corak tafsir al-adabiy al-ijtima'iy adalah merupakan corak penafsiran Alquran dengan menjelaskan atau mengungkap ayat-ayat Alquran berdasarkan ketelitian ungkapan-ungkapan dan disusun dengan menggunakan bahasa yang lugas dan menekankan tujuan pokok turunnya Alquran, lalu di aplikasikan dengan kehidupan sosial. Corak penafsiran ini muncul karena ketidakpuasannya para mufasir yang menganggap bahwa penafsiran Alquran selama ini hanya didominasi oleh tafsir yang menitikberatkan pada nahwu, bahasa dan perbedaan mazhab, baik dalam bidang ilmu kalam, ushul fiqh, sufi, fiqh, dan lain sebagainya. Kemudian kitab tafsir yang menggunakan corak penafsiran al-Adabiy al-Ijtima'i adalah kitab tafsir al-Manar karya Muhammad Abduh dan Rasyid Ridha, kitab Tafsir al-Wadhib karya Muhammad Mahmud al-Hijazy, kitab Tafsir al-Qur'an karya Syaikh Ahmad al-Maraghi dan kitab Tafsir al-Qur'an al-Karim karangan Syaikh Mahmud Syaltut. ${ }^{62}$

\section{E. Kesimpulan}

Dari pembahasan di atas dapat disimpulkan bahwa yang dimaksud dengan metode tafsir adalah suatu cara dan langkah-langkah yang harus ditempuh ketika dalam melakukan penafsiran terhadap Alquran, dalam hal ini terdapat beberapa metode penafsiran Alquran, yaitu; metode tafsir tablili, ijmali, muqaran, maudhu'iy dan hermeneutika. Selain itu, yang dimaksud dengan pendekatan adalah suatu cara pandang atau titik keberangkatan dari prosesnya tafsir, diantara pendekatan

\footnotetext{
"2Imam Musbikin, "Mutiara" Al-Qur'an Khazanah Ilmu Tafsir, (Jawa Timur: Jaya Star Nine, 2014), hlm. 49
} 
tdalam tafsir Alquran, yakni; pendekatan tekstual, kontekstual, bahasa, historis dan sosio-historis. Kemudian maksud dari corak tafsir Alquran adalah suatu nuansa, warna atau kecenderungan pemikiran atau ide yang mendominasi suatu karya tafsir, adapun corak tafsir Alquran adalah corak tafsir falsafi, fiqhi, sufi, 'ilmi, adabi al-ijtima'iy.]

\section{DAFTAR PUSTAKA}

Baidan, Nashruddin, Metode Penafsiran AlQur'an, Yogyakarta: Pustaka Pelajar, 2011.

Metodologi Penafsiran Al-Qur'an, Yogyakarta: Pustaka Pelajar, 2012.

Al-Farmawi, 'Abd al-Hayy, Metode Tafsir Maudhu'iy, Suatu Pengantar, Terj. Suryan A. Jamrah, judul asli, AlBidayah fi al-Tafsir al-Maudhu'iy:Dirasah Manhajiah Mawdhu'iyah, Jakarta: Raja Grafindo Persada, 1994.

Gusmian, Islah, Khazanah Tafsir Indonesia dari Hermeneutika hingga Ideologi, Jakarta Selatan: Khazanah Pustaka Keilmuan, 2003.

Musbikin, Imam, 'Mutiara" Al-Qur'an Khazanah Ilmu Tafsir, Jawa Timur: Jaya Star Nine, 2014.

Al-Qardhawi, Yusuf, Berinteraksi dengan alQur'an, Penerjemah Abdul Hayyi alKhattani, Jakarta: Gema Insani Press, 1999.

Rahmawati, Mohammad Gufron, Ulumul Qur'an: Praktis dan Mudah, Yogyakarta: Teras, 2013.

Rusydi, Ulumul Qur'an I, Padang: IAIN-IB Press, 1999. , Ulumul Qur'an II, Padang: IAINIB Press, 1999.

Sakn, Ahmad Soleh, "Model Pendekatan Tafsir dalam Kajian Islam", Jurnal Ilmu Agama, No. 2, Desember 2013
Salim, Abd Muin, Metodologi Ilmu Tafsir, Yogyakarta: Teras, 2005.

Samsurohman, Pengantar Ilmu Tafsir, Jakarta: Amzah, 2014.

Shihab, M. Quraish, Membumikan al-Qur'an, Fungsi Peranan Wabyu dalam Kebidupan Masyarakat, Bandung: Mizan, 1997. , Kaidah Tafsir, Tangrang: Lentera Hati, 2013.

Sofyan, Muhammad, Tafsir wal Mufassirun, Medan: Perdana Publishing, 2015.

Suma, Muhammad Amin, Ulumul Qur'an, Jakarta: Rajawali Pers, 2013.

Al-Suyuthi, Jalaludin Abd al-Rahman, AlItqan fi Ulum al-Qur'an, Beirut: Dar alMa'rifah, 1978.

Syamsuddi, Sahiron, Hermeneutika AlQur'an Mazhab Yogya, Yogyakarta: Islamika, 2003.

Hermeneutika Pengembangan Ulumul Qur'an, Yogyakarta: Nawesea Press, 20017.

Umiarso, Hassan Hanafi, Pendekatan Hermeneutik dalam Menghidupkan Tuban, dalam Metodologi Studi Islam, Percikan Pemikiran Tokob dalam Membumikan Agama, Yogyakarta: ArRuzz Media, 2013.

Ulya, Berbagai Pendekatan Dalam Studi AlQur'an; Penggunaan Ilmu-ilmu Sosial, Humaniora, dan Kebahasaan dalam Penafsiran al-Qur'an, Yogyakarta: Idea Press, 2017.

Usman, Ilmu Tafsir, (Yogyakarta: Teras, 2009.

Yunus, Muhammad, Kamus Arab-Indonesia, Jakarta: PT Hida karya Agung, 1989.

Yusuf, Kadar M, Studi al-Qur'an, Jakarta: Amzah, 2014.

Zulheldi, 6 Langkah Metode Tafsir Muadh'i, Jakarta: PT Raja Grafindo Persada, 2017. 